\title{
A NEW HYMENOPTEROUS PARASITE UPON ADULT BEETLES.
}

\author{
A. B. GAHAN
}

Branch of Cereal and Forage Crop Insects, Bureau of Entomalogy, U. S. Department of Agriculture

The writer has recently received from $\mathrm{Mr}: \mathrm{W}, \mathrm{V}$. Balduf, Assistant Entomologist of the Ohio Agricultural Experiment Station and graduate student at Ohio State University, specimens of an interesting parasite which appears to be new to science. This parasite is interesting not only because it attacks a well known garden pest; the cucumber beetle (Diabrotica vittata), but it is interesting atso structurally and biologically.

The writer is indebted to $\mathrm{Mr}$. Balduf for the following facts regarding its life history: The parasite attacks the adult beetle by mounting on the back of its host and thrusting its ovipositor into the thorax, apparently through one of the sutures near the base of the elytra, and depositing its egg within. - The parasite larva feeds internally. In its earlier stages it has a sort of tail like terminal appendage which is lost before maturity. The mature larva escapes from the body of its host either at the junction of head and thorax or of the thorax and abdomen, and although the host is not outwardly defaced, it is killed. The parasite larva undergoes its transformation just below the surface of the soil in a closely woven silken cocoon. Pupation lasts approximately ten days. The parasite is not plentiful, having been found in an average of about one or two beetles per hundred late in the summer and somewhat more commonly in May and June.

In its mode of development the parasite reminds one of the common parasite of lady-bird beetles [Dinocampus terminalis Nees], but differs in many important details. It is perhaps more nearly like Perilitus eleodis Viereck, but here again there are marked differences in details, such as the manner and place of oviposition, the place of emergence from the host, and the method of pupation.

Following is a description of the adult female parasite: 


\title{
Superfamily ICHNEUMONOIDEA.
}

Family BRACONIDE.

\author{
Subfamily LJOPHRONINE.
}

\section{Syrrhizus diabrotica, new species.}

This species does not fully agree with the characterization of the genus Syrrhizus Foerster, which is said to have the first cubital and first discoidal cells confluent and the notauli entirely effaced. In the present species the first abscissa of cubitus is only partially obsolete and the notauli are not completely effaced, being represented by a short groove at each lateral anterior angle and a deep dimple-like median fovea or depression near the posterior margin of the mesoscutum. It is apparently intermediate between Syrrhizus on the one hand and both Centistes Haliday and Leiophron Nees on the other, but agrees better with the former than with either of the latter. Considering the evident intergradation of the characters cited, it seems more reasonable to place it in Syrrhizus than to erect a new genus for it at this time.

Female.-Length $2.2 \mathrm{~mm}$. Head viewed from above transverse, a little more than one and one-half times as broad as long, flattened in front and rounded behind, the occipital carina complete and far below the vertex; frons, vertex, occiput and posterior orbits smooth and polished; viewed from in front the head is very slightly broader than high, subtriangular in outline, convexly rounded above and subtruncate below; inner margins of the eyes nearly parallel, a little divergent below; malar space slightly shorter than the width of mandible at base; face hairy and shining, with a longitudinal swelling medially, and very finely and obscurely punctate laterad of the median ridge; antennæ inserted a little above the middle, 24-jointed, the basal joints approximately three times as long as broad, apical joints about twice as long as broad; mesoscutum perfectly smooth and polished, with the notauli effaced except for a short groove at each lateral anterior angle and a deep median fovea near the posterior margin; disk of scutellum smooth and small, with the transverse groove between it and the mesoscutum very broad and divided in the middle by a single longitudinal carina: lateral face of scutellum strongly rugose; metanotum longitudinally striate; propodeum rugulose except at anterior middle, with a median longitudinal carina on the anterior half and a distinct transverse carina extending completely across the sclerite a little behind the middle, the posterior face with several irregular longitudinal raised lines; spiracles small and round; mesopleura mostly smooth with the groove shallow and more or less weakly foveolate or rugulose; stigma of forewing 
broad; first abscissa of radius not half as long as the width of stigma, the second abscissa long and curved, not reaching to the wing apex; metacarpus a little longer than the anterior margin of stigma; basal half of first abscissa of cubitus effaced, the first cubital and first discoidal cells incompletely confluent; cubital vein beyond the intercubitus obsolescent; nervulus postfurcal by nearly its own length; first brachial cell narrowly open at its posterior outer angle; abdomen subequal to the thorax in length, curved downward at apex; first tergite increasing gradually in width from base to apex, longitudinally striate, about twice as broad at apex as at base and a little more than one and one-half times as long as broad at apex; second and following tergites perfectly smooth, the second large and occupying most of the dorsal length of abdomen, tergites beyond the second bent downward; ovipositor curved sharply downward and forward, the ovipositor sheaths broad, narrowed at base and apex and a little shorter than the length of first tergite.

Black; five or six basal joints of antennæ, mandibles, clypeus, palpi, and all legs including their coxæ pale reddish testaceous; face, prothorax and the mesopleura more or less reddish brown to piceous; tarsal claws, and antennæ except base of latter dark brown; wings hyaline, stigma and veins dark brown except medius and submedius which are pale; ovipositor testaceous, its sheaths black.

Male unknown.

Type locality.-Marietta, Ohio.

Type.-Cat. No. 25064, U. S. N. M.

Host.-Diabrotica vittata (Fabricius).

Type and three paratype females received from W. V. Balduf, of the Ohio Agricultural Experiment Station, by whom they were reared June 29 and July 2, 1921, from adults of the cucumber beetle. 